\title{
For a BRICS Agenda on Culture and the Creative Economy
}

\author{
LILIAN RICHIERI HANANIA AND ANTONIOS VLASSIS
}

\section{Introduction}

This chapter highlights how culture and creative industries may support the BRICS's contribution to global governance and help it to make a difference in tackling domestic and global problems. As emerging economies with contrasting features, the BRICS countries should embrace opportunities created both by their aincreased collaboration and by the so-called creative economy, which is characterized by business convergence and interdependence resulting from technological innovation and creativity. ${ }^{1}$ By so doing they would benefit not only from economic growth but also from fundamental conditions conducive to more human and sustainable development in increasingly multicultural societies. The respect and promotion of cultural diversity are a prerequisite for the BRICS countries to benefit not only from economic growth but also from fundamental conditions conducive to more human and sustainable development in increasingly multicultural societies, which has implications regarding democracy and pluralism - which unfortunately remain a challenge in some of those countries. ${ }^{2}$

'Cultural diversity' is understood here according to the 2005 United Nations Educational, Scientific and Cultural Organization (UNESCO)

\footnotetext{
${ }^{1}$ Rostam J. Neuwirth, 'Global Market Integration and the Creative Economy: The Paradox of Industry Convergence and Regulatory Divergence' (2015) 18(1) Journal of International Economic Law 21-50.

2 For instance, see Jonathan McClory, 'Creative Russia: lessons from Berlin', The Guardian, 2013; available at www.theguardian.com/culture-professionals-network/cultureprofessionals-blog/2013/sep/25/russia-culture-st-petersburg-berlin [accessed on 8 March 2016], who states, 'The future development of Russia's creative industries is surely stymied by the country's current political climate and its opposition to political and cultural diversity'.
} 
Convention on the Protection and Promotion of the Diversity of Cultural Expressions (CDCE). ${ }^{3}$ It 'refers to the manifold ways in which the cultures of groups and societies find expression ..., whatever the means and technologies used' (article 4.1 CDCE).

Since '[c]ultural diversity can be protected and promoted only if human rights and fundamental freedoms, such as freedom of expression, information and communication, as well as the ability of individuals to choose cultural expressions, are guaranteed' (article 2.1 CDCE), it implies the 'recognition of equal dignity of and respect for all cultures, including the cultures of persons belonging to minorities and indigenous peoples' (article 2.3 CDCE) as well as of vulnerable groups in general. Moreover, cultural diversity is 'one of the roots of development, understood not simply in terms of economic growth, but also as a mean to achieve a more satisfactory intellectual, emotional, moral and spiritual existence' (article 3 of the Universal Declaration on Cultural Diversity - UDCD). ${ }^{4}$ The contribution of cultural diversity to sustainable development is confirmed in the CDCE (Preamble, articles 2.6 and 13 CDCE).

The CDCE focuses on cultural goods, services and industries, adopting as such an economic and material perspective. It offers a comprehensive framework for cultural policies and international cultural cooperation with the aim of attaining more balanced international exchanges of cultural goods and services and therefore better global governance of the cultural sector. It responds pertinently to the creative economy and should be used as a coordination framework to promote regulatory coherence' in such a context. ${ }^{5}$ Since its negotiations the CDCE has generated the inclusion of cultural considerations in international discussions and in the last several years has become fundamental in efforts to achieve

${ }^{3}$ UNESCO, Convention on the Protection and Promotion of the Diversity of Cultural Expressions, adopted on 20 October 2005 and in effect since March 2007; available at http:// en.unesco.org/creativity/convention/about/2005-convention-text [accessed on $25 \mathrm{March}$ 2016]. On this convention, its purpose and its object, see Lilian Richieri Hanania, Diversité culturelle et droit international du commerce (Paris: La Documentation française, 2009), as well as Lilian Richieri Hanania (ed.), Cultural Diversity in International Law: The Effectiveness of the UNESCO Convention on the Protection and Promotion of the Diversity of Cultural Expressions (London: Routledge, 2014); and Antonios Vlassis, Gouvernance mondiale et culture: de l'exception à la diversité (Liège: Presses universitaires de Liège, 2015).

${ }^{4}$ UNESCO, Universal Declaration on Cultural Diversity, 2001, available at http://unesdoc .unesco.org/images/0012/001271/127162e.pdf [accessed on 22 March 2016].

5 On this subject see Lilian Richieri Hanania, 'The UNESCO Convention on the Diversity of Cultural Expressions as a coordination framework to promote regulatory coherence in the creative economy' (2015) International Journal of Cultural Policy 1-20. 
better and socially mindful global governance. Among other things, it has contributed to the recognition of the role of culture in the United Nations (UN) Sustainable Development Goals (SDGs) in 2015. ${ }^{6}$

Despite the different positions defended by the BRICS countries during the CDCE negotiations, notably regarding its relationship with other international treaties, particularly with trade agreements, ${ }^{7}$ we propose that the CDCE should be at the heart of a future BRICS agenda on the creative economy. Four members of the BRICS are already parties to the CDCE: India since 15 December 2006, South Africa since 21 December 2006, Brazil since 16 January 2007 and China since 30 January 2007. The first step in such an agenda would be the CDCE ratification by the Russian Federation.

The BRICS's rapprochement regarding the explicit integration of culture in the UN SDGs offers interesting perspectives for the cultural field. A landmark in the 2012-2015 international mobilization in favor of the inclusion of culture in the post-2015 development agenda, 'Culture: Key to Sustainable Development', an international congress, was held in China in May 2013. Organized by the Hangzhou local authorities and UNESCO, which had developed strong links since the inscription of the West Lake Cultural Landscape of Hangzhou within the UNESCO World Heritage List in $2011,{ }^{8}$ this international meeting was attended by 500 participants from eighty-two countries, including representatives of national authorities, civil society and academics from the BRICS countries. ${ }^{9}$ The BRICS

6 United Nations, Transforming our World: The 2030 Agenda for Sustainable Development, Resolution adopted by the General Assembly on 25 September 2015, Seventieth session, A/RES/70/1, 21 October 2015; available at www.un.org/ga/search/view_doc.asp? symbol=A/RES/70/1\&Lang=E [accessed on 16 March 2016].

7 China and South Africa favored nonsubordination of the CDCE to trade agreements, while India objected to a binding convention that could counterbalance the international trade regime. The Chinese delegation noted that 'the Convention should become a reference for the World Trade Organization and other international bodies. In this regard, all the international regimes would function as a whole' (free translation) See UNESCO, Avant-projet de Convention sur la protection de la diversité des contenus culturels et des expressions artistiques: Partie II: commentaires spécifiques des Etats-membres (2004), p. 87.

8 Antonios Vlassis, 'Culture in the post-2015 development agenda: the anatomy of an international mobilization' (2015) 36(9) Third World Quarterly 1649-62.

9 Forty-six participants from China; seven participants from India, notably experts in the field of cultural heritage and the craft industry; and two each from Russia, Brazil and South Africa. See UNESCO, List of Attendees to the Congress; available at www.unesco .org/new/fileadmin/MULTIMEDIA/HQ/CLT/pdf/Book15.pdf [accessed on 13 April 2016]. One of the main outcomes of the congress was the 'Hangzhou Declaration', which included nine actions to place culture at the core of policies for sustainable development. 
countries seemed to be divided on the link between culture and sustainable development, however. In September 2013, the Group of Friends on Culture and Development was launched within the UN General Assembly with nearly thirty countries, including South Africa and Brazil, but China, India and Russia decided not to join. In addition, UNESCO organized two special thematic debates on 'Culture and Development' at the UN General Assembly in 2013 and 2014. Although many high representatives from economically developing countries participated in the debates, the only representative from a BRICS country was the minister of culture from South Africa.

Nevertheless, in the 2015 BRICS Agreement on Cooperation in the Field of Culture, ${ }^{10}$ the BRICS explicitly recognized 'the contribution of cultural heritage to the sustainable development agenda' (article 4) and creative industries 'as a pillar of sustainable development' (article 12). The 2016 Goa Declaration adopted at the eighth BRICS Summit recognized 'the important role of culture in sustainable development and in fostering mutual understanding and closer cooperation' as well. ${ }^{11}$ The adoption of the 2030 Agenda for Sustainable Development, with cultural concerns notably being included in paragraphs 8 and 36 of the SDGs Declaration, ${ }^{12}$ as well as Targets $4.5,4.7,8.9,11.4$ and $12 . b,{ }^{13}$ should also ultimately help

See UNESCO, 'The Hangzhou Declaration: heralding the next era of human development'; available at www.unesco.org/new/en/culture/themes/dynamic-content-single-view/ news/the_hangzhou_declaration_heralding_the_next_era_of_human_development/\# .Vw5mtKSLShc [accessed on 13 April 2016].

10 BRICS, Agreement between the Governments of the BRICS States on Cooperation in the Field of Culture, Ufa, Russia, 9 July 2015; available at www.brics.utoronto.ca/docs/ 150709-culture-agreement-en.html [accessed on 5 April 2016].

11 The Indian Express, '8th BRICS Summit Goa Declaration: Here is the full text adopted by the member nations', 16 October 2016; available at http://indianexpress .com/article/india/india-news-india/8th-brics-summit-goa-declaration-here-is-the-fulltext-adopted-by-the-member-nations/ [accessed on 1 December 2016].

12 Paragraph 8 reads, 'We envisage a world of universal respect for human rights and human dignity, the rule of law, justice, equality and non-discrimination; of respect for race, ethnicity and cultural diversity'; and paragraph 36: 'We pledge to foster intercultural understanding, tolerance, mutual respect and an ethic of global citizenship and shared responsibility. We acknowledge the natural and cultural diversity of the world and recognize that all cultures and civilizations can contribute to, and are crucial enablers of, sustainable development' (United Nations, Transforming our World, pp. 4, 10).

13 These targets refer to Goals 4 ('Ensure inclusive and equitable quality education and promote lifelong learning opportunities for all'), 8 ('Promote sustained, inclusive and sustainable economic growth, full and productive employment and decent work for all'), 11 ('Make cities and human settlements inclusive, safe, resilient and sustainable') and 12 ('Ensure sustainable consumption and production patterns'). (United Nations, Transforming our World, pp. 17, 20, 22, 23). 
diminish differences and encourage engagement among the BRICS countries on this matter.

Attempts to attain the SDGs and promote economic growth through the strengthening of creative industries require actions at the local, national and international levels. The CDCE offers a suitable legal framework for national policies and international cooperation to create a favorable environment for creativity and cultural diversity. ${ }^{14}$ A BRICS agenda on the creative economy should address these two aspects: the adoption and implementation of appropriate national cultural policies and measures (Section I) and the enhancement of international cultural cooperation (Section II).

\section{National Cultural Policies and Measures}

The CDCE recognizes the legitimacy of policies and measures 'related to the protection and promotion of the diversity of cultural expressions' (article $3 \mathrm{CDCE}$ ) and reaffirms the parties' sovereign right to act in favor of the diversity of cultural expressions within their territory (articles 2.2 and $5 \mathrm{CDCE}$ ). Its call for the parties to integrate culture into development policies, as well as its flexibility regarding cultural policies, allows countries to implement the CDCE in different fields. Policies legitimated under the CDCE may, for instance, focus on cultural heritage, if needed to protect and promote the diversity of cultural expressions (notably for countries that are not parties to the 2003 Convention for the Safeguarding of the Intangible Cultural Heritage, but are parties to the CDCE, e.g. South Africa), ${ }^{15}$ or may even be adopted outside traditional cultural sectors (e.g.

14 The 2003 UNESCO Convention for the Safeguarding of the Intangible Cultural Heritage (CSICH), adopted on 17 October 2003 and in effect since 20 April 2006; available at www .unesco.org/culture/ich/en/convention [accessed on 4 April 2016], might also have a complementary role to play for some of the BRICS countries. In fact, China, India and Brazil are among the main players regarding the CSICH implementation and as of June 2017, they have inscribed fifty-nine elements on the List of Intangible Cultural Heritage - 39, 12 and 8, respectively. These countries see traditional cultural resources and contemporary cultural expressions as a continuum and tend to include under the term of 'creative economy' many cultural pursuits that might be identified as intangible cultural heritage. See UNESCOUNDP, Creative Economy Report 2013 Special Edition: Widening Local Development Pathways (Paris: UNESCO-UNDP, 2013), p. 69. By contrast, South Africa is not a party to the $\mathrm{CSICH}$, whereas Russia has inscribed only two elements on the above-mentioned list.

15 See, on the link between the two conventions, Lilian Richieri Hanania, 'Protection mechanisms for cultural expressions under threat' (2014) 2 Transnational Dispute Management Art and Heritage Disputes 2-6; available at www.transnational-dispute-management.com/ article.asp?key=2095 [accessed on 4 April 2016]. 
varied sectors involved with information and communications technology (ICT) in the digital age). ${ }^{16}$ In the context of the creative economy, those policies and measures require a high level of creativity and openness to the future from lawyers and policy makers. ${ }^{17}$

To take full advantage of their creative potential, the BRICS nations should map their creative sectors to identify their weaknesses and strengths, thereby enabling appropriate policies to be adopted and implemented to create the right environment for cultural and creative industries. Such an environment should encourage individuals and social groups: (a) to create, produce, disseminate, distribute and have access to their own cultural expressions' (article 7(a) CDCE). It should also foster 'access to diverse cultural expressions from within their territory as well as from other countries of the world' (article 7(b) CDCE). Policies might focus on specific communities and sectors or be transversal, ${ }^{18}$ targeting mainstream effects, such as investments in infrastructure, innovation, new technologies, education, and capacity building as well as an effective respect for fundamental freedoms.

The following subsections provide a brief overview of the state of the BRICS countries' cultural industries and their existing cultural policies, testifying once more to significant discrepancies among them.

\section{A. The BRICS Countries' Cultural Industries}

According to a recent study, global 'cultural exports have doubled over the past 10 years, reaching a total of USD 212.8 billion in

16 Lilian Richieri Hanania, 'Le débat commerce-culture à l'ère numérique: quelle application pour la Convention de l'UNESCO sur la diversité des expressions culturelles?' (2015), 3-10; available at http://papers.ssrn.com/sol3/papers.cfm?abstract_id=2600647 [accessed on 4 April 2016], as well as Lilian Richieri Hanania, 'The UNESCO Convention on the Diversity of Cultural Expressions as a coordination framework', 6-10' and Lilian Richieri Hanania, L'extension de l'exception culturelle aux secteurs issus des nouvelles technologies, RIJDEC, Le renouvellement de l'exception culturelle à l'ère du numérique (2015); available at www.coalitionfrancaise.org/wp-content/uploads/2015/10/ RIJDEC-Le-renouvellement-de-lexception-culturelle-\%C3\%A0-1\%C3\%A8re-du-num \%C3\%A9rique-22-10-15.pdf [accessed on 4 April 2016].

17 Rostam J. Neuwirth, 'The UNESCO Convention and future technologies: a journey to the center of cultural law and policymaking', in Lilian Richieri Hanania and Anne-Thida Norodom (eds.), Diversity of cultural expressions in the digital era (Buenos Aires: Teseo, 2016), available at www.teseopress.com/diversityofculturalexpressionsinthedigitalera/ [accessed on 4 April 2016].

${ }_{18}$ CISAC, The Creative Industries and the BRICS - A Review of the State of the Creative Economy in Brazil, Russia, India, China and South Africa (CISAC, 2014); available at www.cisac .org/Media/Studies-and-Reports/Publications-PDF-files/CISAC-BRICS-STUDY-20146 [accessed on 4 April 2016], p. 5. 
2013.'19 Regarding trade in cultural services, the available statistics show that exports increased globally on average by 10 percent annually between 2003 and 2012, accounting for USD 150 billion in 2013. ${ }^{20}$ Despite the growing importance of the creative sectors in the BRICS economies, 'the BRICS ... have not yet unlocked the full economic potential and benefits of the creative economy. The economic contribution of the creative industries to the GDP of BRICS countries is between 1-6\% only', while in the United States, for instance, such industries account for 11 percent of the GDP. ${ }^{21}$ In addition, the economic benefits deriving from cultural diversity and creativity ${ }^{22}$ may result not only from the activity of cultural and creative industries per se but also and more generally from the creativity and innovation that cultural diversity brings to the economy. ${ }^{23}$

The BRICS countries have, nevertheless, expanded their participation in the cultural sector, with China, Brazil and Russia controlling 436, 310 and 219 affiliates abroad in the sectors of publishing, printing and recorded media in 2012, respectively. ${ }^{24}$ Moreover, since 2010 China has been the leading exporter of cultural goods in the world, and India has emerged as the fifth-largest exporter of those goods. ${ }^{25}$ In the global market in 2013, visual arts and crafts accounted for 71 percent of exports of cultural goods, showing an increase of 185 percent between 2004 and 2013 mostly due to trade in jewelry (gold). ${ }^{26}$ The value of South Africa's exports of cultural and natural heritage goods also doubled from 2004 to

19 UNESCO and UIS, Cultural Trade Flows Infographic (2016); available at www.uis.unesco .org/culture/Documents/cult-trade-infographic-final-EN.pdf [accessed 22 March 2016].

${ }^{20}$ UNESCO and UIS, The Globalisation of Cultural Trade: A Shift in Consumption - International Flows of Cultural Goods and Services 2004-2013 (2016), p. 69; available at www .uis.unesco.org/culture/Documents/international-flows-cultural-goods-report-en.pdf [accessed on 22 March 2016]. According to the 2009 UNESCO Framework for Cultural Statistics, cultural domains comprise cultural and natural heritage; performance and celebration; visual arts and crafts; books and press; audiovisual and interactive media; and design and creative services, including architecture, design and advertising services. Ibid., pp. 13-14.

${ }^{21}$ CISAC, The Creative Industries and the BRICS, pp. 4, 10. Growth in exports of creative goods 'significantly outpace[s] global economic growth' (ibid., p. 4).

22 See, for instance, UNCTAD, World Creative Economy Report 2010 - Creative Economy: A Feasible Development Option (Geneva: UNCTAD, 2010); available at http://unctad.org/en/ Docs/ditctab20103_en.pdf [accessed on 25 March 2016].

${ }^{23}$ See, for instance, articles 1 and 9 UDCD and Lilian Richieri Hanania, 'Bringing cultural diversity to discussions on social and labor issues', pp. 121-135. Regarding the effects of this link on international trade agreements, see Lilian Richieri Hanania, 'The UNESCO Convention on the Diversity of Cultural Expressions as a coordination framework', 1-20 and 'Le débat commerce-culture à l'ère numérique', 3-10.

${ }^{24}$ UNESCO and UIS, The Globalisation of Cultural Trade, p. 79.

${ }^{25}$ Ibid., pp. 11 and $33 . \quad{ }^{26}$ Ibid., pp. 39 and 45. 
Table 15.1 Film Production/National Market Share (\%)

\begin{tabular}{lllll}
\hline \hline & 2011 & 2012 & 2013 & 2014 \\
\hline China & $588 / 53.6$ & $745 / 48.5$ & $638 / 58.7$ & $618 / 54.5$ \\
India & $1255 / 89$ & $1602 / 91.5$ & $1724 /-$ & $1966 /-$ \\
Russia & $64 / 15.8$ & $75 / 16.1$ & $73 / 18.4$ & $123 / 18.7$ \\
Brazil & $100 / 12.4$ & $83 / 10.3$ & $129 / 18.6$ & $114 / 12.3$ \\
South Africa & $25 / 17$ & $19 /-$ & $25 / 11.2$ & $23 / 6.3$ \\
\hline \hline
\end{tabular}

Source: European Audiovisual Observatory, Focus: World Film Market Trends (2005-2015).

2013. ${ }^{27}$ The future of creative industries has also been considered promising for Russia, ${ }^{28}$ despite the lack of governmental incentives, a few reasons being the absence of clear policies for the creative sector, excessive bureaucracy and corruption, as well as the fact that 'most cultural organizations are still state-owned and their participation in commercial activities is somewhat restricted in the law. ${ }^{29}$

The global cinema market offers useful insights into the expansion of the film industry in the BRICS. Although the five countries actively participate in the global film market, the disparities are significant between India and China, on the one hand, and Russia, Brazil and South Africa, on the other, in terms of cinema production and the national market share (Table 15.1). China remains the most important cinema market in terms of gross box office receipts, followed by India and Russia (Table 15.2). South Africa is one of the few African countries with a structured film industry based on networks of production studios, distribution and exhibition chains and one of the continent's largest theatrical markets. Moreover, China shows the highest and steadiest growth potential, whereas the

27 Ibid., p. 42.

${ }^{28}$ Ibid., p. 10. Moscow has recently hosted the First World Summit for Creative Industries. See Rossiyskaya Gazeta, 'Moscow will host the World Summit for Creative Industries', Russia beyond the Headlines, 2014; available at http://rbth.com/business_calendar/2014/03/04/ moscow_will_host_the_world_summit_for_creative_industries_34761.html [accessed on 8 March 2016].

${ }^{29}$ Katja Ruutu, Aleksander Panfilo, and Päivi Karhunen, Cultural Industries in Russia - Northern Dimension Partnership on Culture (2009), pp. 9-10; available at www .northerndimension.info/images/Cultural_Industries_in_Russia.pdf [accessed on 4 April 2016]. 
FOR A BRICS AGENDA ON CULTURE AND THE CREATIVE ECONOMY 341

Table 15.2 Gross Box Office (in USD Billion)/Average Admissions per Capita

\begin{tabular}{lllll}
\hline \hline & 2011 & 2012 & 2013 & 2014 \\
\hline China & $2.03 / 0.3$ & $2.74 / 0.3$ & $3.54 / 0.4$ & $4.82 / 0.6$ \\
India & $1.47 / 2.2$ & $1.60 / 2.5$ & $1.60 / 2.2$ & $1.50 / 2.0$ \\
Russia & $1.17 / 1.2$ & $1.20 / 1.1$ & $1.34 / 1.2$ & $1.15 / 1.2$ \\
Brazil & $0.86 / 0.7$ & $0.84 / 0.8$ & $0.74 / 0.7$ & $0.82 / 0.8$ \\
South Africa & $0.05 / 0.4$ & $0.09 / 0.5$ & $0.09 / 0.7$ & $0.07 /-$ \\
\hline \hline
\end{tabular}

Source: European Audiovisual Observatory, Focus: World Film Market Trends (2005-2015).

film market growth of India, Russia, Brazil and South Africa fluctuates (Table 15.2).

\section{B. Existing Action for Creative Industries}

Taking the illustration of the film industry, China has developed strict and centralized cinema policies supporting the national film industry via tariffs, quotas, subsidies and tax credits (and, unfortunately, censorship), ${ }^{30}$ whereas India remains characterized by very low state intervention in the film industry, a commercially dynamic private entertainment industry, a strongly decentralized film system and prolific cinema production, shot in more than twenty local languages. ${ }^{31}$ South Africa's film policy aims to attract foreign film productions. For their part, Russia and Brazil have developed film policies marked by screen quotas: in 2012 Russia introduced a 20 percent quota for Russian films in cinemas, while in Brazil since 1932 a minimum number of days a year must be devoted to local productions. ${ }^{32}$ In addition, both countries have various co-production treaties. Russia joined the European co-production fund Eurimages in 2011 and has film agreements with major European countries such as Italy, France, Spain and Germany. Brazil has several co-production agreements with Latin American and European countries and is a main pillar

30 Antonios Vlassis, 'Soft power, global governance and rising powers: the case of China' (2016) 22(4) International Journal of Cultural Policy 481-96.

31 Antonios Vlassis, 'Les puissances émergentes dans la bataille mondiale de l'attraction: Bollywood, vecteur du soft power de l'Inde' (2016) 55 Interventions Économiques 1-21; available at https://interventionseconomiques.revues.org/2867 [accessed on 4 April 2016].

32 See Lilian Richieri Hanania, Diversité culturelle et droit international du commerce, p. 71. 
of the multilateral co-production program IBERMEDIA, which includes Spain, Portugal and several countries in Latin America. With regard to national support, the Russian Cinema Fund, a public funding system established in 2010 with a budget of USD 110 million, has provoked criticism, since a big portion of its funding is distributed to seven leading production companies. ${ }^{33}$

More broadly, South Africa provides an interesting example of a dynamic partnership between civil society and national authorities in the cultural sector. The Cultural and Creative Industries Federation, created in 2014, aims to prevent the fragmentation of the sector and to foster its economic potential. It is built on a strong partnership among several South African stakeholders, such as the Ministry of Arts and Culture, the Department of Trade and Industry, the Department of Communications and many players in the cultural and creative industries.

According to the quadrennial reports from the CDCE parties, ${ }^{34}$ between 2005 and 2010, China opened up a range of cultural industry sectors to nonpublic capital and supported private performing groups via funding, government procurement, performance venues and equipment, simplified approval processes, talent cultivation and commendation as well as rewards.

The Brazilian Ministry of Culture has organized a series of workshops on cultural policies for artists and cultural professionals and entrepreneurs in all the states of the Federation. The Brazilian international audiovisual cooperation policy, aimed at international co-productions and the promotion of Brazilian films in the international audiovisual market (through the allocation of USD 35.7 million), is also an important innovative initiative. Moreover, the 'Creative Brazil Plan' is part of the strategy to promote the creative economy ${ }^{35}$ but faces several challenges, ${ }^{36}$ including

33 In 2010, the Federal Antimonopoly Service called for more transparency in the Russia Cinema Fund's decision-making procedures. See European Audiovisual Observatory, Focus: World Film Market Trends (Strasbourg: European Audiovisual Observatory, 2005-2016).

${ }^{34}$ Brazil submitted its report in 2012, China in 2013 and India in 2015. South Africa has still not provided its report. See UNESCO, Periodic Reports - Innovative Examples; available at http://en.unesco.org/creativity/monitoring-and-reporting/periodic-reports/ innovative-examples [accessed on 13 April 2016].

${ }^{35}$ For more information on Brazilian policies for the diversity of cultural expression, see Brazil, Relatório periódico quadrienal sobre as medidas para proteger e promover a diversidade das expressões culturais (2012); available at http://en.unesco.org/creativity/sites/ creativity/files/periodic_reports/old/brazil_report_ownformat_pt_2012.pdf [accessed on 4 April 2016].

${ }^{36}$ Claudio Accioli, Kalinka Iaquinto, Solange Monteiro and Thais Thimoteo, 'Can Brazil become a creative economy?' (2011) Brazilian Economy 20-8. 
instability and a lack of continuity in policies, as illustrated by the rapid dissolution of the Creative Economy Secretariat within the Brazilian Ministry of Culture. Finally, Brazilian local and grassroots cultural initiatives have been fostered through the creation of 'Culture Points' all over the country within the 'Living Culture' program. ${ }^{37}$ Part of a national cultural system that brings together Brazilian states and municipalities, the 'Living Culture' program considers culture to be a key factor in the development of and access to citizenship.

Such a local perspective, close to citizens, seems to be a fundamental factor in the effectiveness of national policies and measures that intend to promote creativity, cultural diversity and the flourishing of creative industries. Indeed, '[i]t is first and foremost at [the] local level that culture and creativity are lived and practised on a daily basis. ${ }^{38}$ The promotion and multiplication of 'creative cities' in the BRICS countries may be a step in that direction. Except for South Africa, 'creative cities' have been acknowledged in the BRICS countries by UNESCO and incorporated into the UNESCO Creative Cities Network (UCCN) created in $2004 .{ }^{39}$ Each of these cities is recognized as having placed creativity and cultural industries at the heart of sustainable urban development, local development plans, and cooperation at the international level. Indeed, to foster access by their citizens to diversified cultural offerings, international cultural cooperation must be reinforced as well.

\section{International Cultural Cooperation}

Following previous summit declarations, the BRICS Agreement on Cooperation in the Field of Culture was adopted in 2015. ${ }^{40}$ Still subject to

37 See Giuliana Kauark and Lilian Richieri Hanania, 'Social and cultural development through cultural diversity - the Living Culture Programme', in Mapping Cultural Diversity Good Practices from around the Globe (Asia-Europe Foundation, German Commission for UNESCO and U40 Group, 2010), pp. 17-21; available at www.unesco.de/fileadmin/ medien/Dokumente/Kultur/U40/Mapping_Cultural_Diversity_FINAL.pdf [accessed on 4 April 2016].

38 UNESCO, UNESCO Creative Cities Network, 'Why creativity? Why cities?' 2016; available at http://en.unesco.org/creative-cities/content/why-creativity-why-cities [accessed on 30 March 2016].

39 UNESCO, UNESCO Creative Cities Network (2016); available at http://en.unesco.org/ creative-cities/home [accessed on 30 March 2016]. The UCCN is currently composed of 116 cities, including 5 cities in Brazil (Florianópolis, Curitiba, Santos, Belém and Salvador), 1 in the Russian Federation (Ulyanovsk), 2 in India (Varanasi and Jaipur) and 8 in China (Beijing, Chengdu, Hangzhou, Shanghai, Shunde, Suzhou, Shenzhen and Jingdezhen).

40 BRICS, Agreement between the Governments of the BRICS States on Cooperation in the Field of Culture. 
ratification, and despite being very vaguely worded and weakly binding, it represents the first step in the strengthening of cooperation by the BRICS countries regarding different cultural sectors.

In its preamble, it recalls the commitment of those countries to 'openness, inclusiveness, equality, respect for cultural diversity, and mutual respect and learning. While referring to the laws and policies of their states,' the agreement reflects the obligation by the parties to 'develop and promote cooperation and exchanges' in several cultural sectors. The areas of cooperation include 'music and dancing, choreography, theatre, circus, archives, publishing and libraries, museums, cultural heritage, fine, decorative and applied arts, audio-visual works, and ... other creative activities provided for by [the] Agreement' (article 1) as well as intangible cultural heritage (article 4) and traditional knowledge and cultural expressions (article 7).

Cooperation should cover the following: training; skills upgrading; exchanges of researchers, experts and students; joint programs and exchange of information (article 2); prevention of illicit importing, exporting and transferring of cultural property (article 3); 'protection, preservation, restoration, return and utilisation of cultural heritage objects'; support and assistance in managing cultural heritage sites and in inscribing those sites in the World Heritage List (article 4); organization of festivals, exhibitions and performances of traditional expressions (article 6); consultations on matters of common interest (article 7); exchanges involving young teams and performers (article 8); 'exchange of copies of documents and materials related to the culture, history, social and political development' of each BRICS country (article 9); cooperation among libraries and museums (article 10); book translation and exchanges in the printing and publishing sector (article 11); cooperation among agencies in the field of creative industries (article 12); and selection, co-production and exchanges of audiovisual works and 'participation of audio-visual professionals in international activities as per the rules and regulations of the Parties' states' (article 5). In fact, audiovisual co-production efforts among the BRICS countries have so far been quite limited. In 2014, India signed audiovisual co-production treaties with China and Brazil, whereas coproduction agreements between China and Brazil, China and Russia, and India and Russia are currently under discussion.

The 2015 agreement is without prejudice to other multilateral exchanges and bilateral cooperation among the BRICS countries. It could particularly stimulate international cooperation among the BRICS countries that are parties to the CDCE. Most importantly, it could ultimately 
contribute to welding together the BRICS countries around cultural issues, building common positions and creating momentum for action - and perhaps leading to ratification of the CDCE by Russia and more active participation in its implementation by India and South Africa, which seem to have kept a low profile regarding the convention.

Using the CDCE as a framework for cooperation with regard to cultural and creative industries, collaboration among the BRICS countries should imply, inter alia, addressing together situations of vulnerability of cultural expressions; promoting dialogue on cultural policy; encouraging professional cultural exchanges and sharing best practices to improve cultural public sector institutions; strengthening partnerships with and among civil society, NGOs and the private sector; sharing information, data, knowledge and expertise; promoting the use of new technologies; and encouraging co-production and co-distribution agreements (articles 12 and 19 CDCE). Joint and collaborative projects should be set up in all those fields. Coordination among the BRICS countries that are parties to the CDCE pursuant to article 21 should likewise be promoted in different international fora. The significant differences in circumstances existing in those countries may undoubtedly have a positive impact in motivating the countries to develop new and innovative solutions and proposals for global challenges.

Furthermore, the BRICS countries should contribute to the International Fund for Cultural Diversity (IFCD, article 18 CDCE), ${ }^{41}$ investing in projects in developing and least developed countries selected according to the principles of the CDCE and with no 'political, economic or other conditions that are incompatible with [its] objectives' (article 18.6 CDCE). Since the IFCD may benefit projects both in the BRICS and in lower-income countries, it could be the first tool to address the CDCE principle of 'international solidarity and cooperation' aiming at 'enabling countries... to create and strengthen their means of cultural expression, including their cultural industries' (article 2.4 CDCE).

As of June 2017, China's contribution to the IFCD amounts to USD 470,000 , far more than the contribution of very developed countries in terms of cultural industries and the main actors in international development aid; for example, Denmark, Sweden, Italy, Australia and the United Kingdom. India's contributions to the IFCD have been irregular,

${ }^{41}$ See Antonios Vlassis, 'Culture development and technical and financial assistance on the basis of the Convention', in Richieri-Hanania (ed.), Cultural Diversity in International Law, pp. 167-80. 
reaching USD 45,000. However, no Chinese or Indian project has received IFCD funds so far. Both an important donor and a receiver, Brazil has contributed USD 300,000 to the IFCD, and two Brazilian projects have received resources from it: a project providing training to indigenous filmmakers with a focus on programming for children (USD 97,580) and a project for empowering indigenous creators from different communities in Brazil by promoting their participation in the digital publishing sector (USD 90,950). South Africa contributed USD 11,000 once to the IFCD in 2009, but remains one of the most dynamic countries in terms of receiving IFCD resources, revealing an effective partnership between civil society and national authorities in the cultural sector. ${ }^{42}$ Five projects have been funded (USD 410,000 in total) dealing with capacity and creative industry development.

Finally, cooperation among the BRICS countries in favor of lowerincome countries could provide the latter with best practices and lessons learned. The significant differences existing among the BRICS countries would be an advantage in that respect, allowing for easier replicability and adaptability of policies and measures according to national circumstances. The CDCE may also provide guidance in this respect. Its article 14 ('Cooperation for Development') highlights the specific needs of developing countries and the objective of fostering 'the emergence of a dynamic cultural sector'. Among the means to be used, it includes the strengthening of cultural industries, 'capacity-building through the exchange of information, experience and expertise, as well as the training of human resources', transfer of technology and know-how and financial support. The latter could be sought inter alia through the BRICS' New Development Bank (NDB BRICS). ${ }^{43}$

Innovative collaborative partnerships should equally be sought and 'shall, according to the practical needs of developing countries, emphasize

${ }^{42}$ It is noteworthy that national coalitions for cultural diversity were established in South Africa and in Brazil before the CDCEadoption. The first national coalition was created in Canada in 1998 to mobilize the country's cultural organizations. At the present date, there are forty-three national coalitions, gathering more than 600 professional organizations in the cultural field that are main players in the CDCE implementation. On the contrary, there are no coalitions for cultural diversity in China, Russia and India.

43 The NDB BRICS 'shall mobilize resources for infrastructure and sustainable development projects in BRICS and other emerging economies and developing countries' and 'shall support public or private projects through loans, guarantees, equity participation and other financial instruments. See article 1, BRICS, Agreement on the New Development Bank (2014), Fortaleza, Brazil, 15 July 2014; available at http://ndbbrics.org/agreement.html [accessed on 11 April 2016]. 
the further development of infrastructure, human resources and policies, as well as the exchange of cultural activities, goods and services' (article 15 CDCE). Furthermore, the BRICS countries, guided by the CDCE, could 'facilitate cultural exchanges with developing countries by granting, through the appropriate institutional and legal frameworks, preferential treatment to artists and other cultural professionals and practitioners, as well as cultural goods and services from developing countries' (article 16 CDCE). In fact, despite the difficulty in characterizing the BRICS as 'developed countries' under the CDCE, the operational guidelines on article 16 of the CDCE have surpassed 'pure operationalization' by adding this statement: 'developing countries are encouraged to offer a preferential treatment to other developing countries, in the framework of South-South cooperation. ${ }^{4}$

\section{Conclusion}

The BRICS should embrace opportunities generated by the creative economy through the elaboration of a strategic agenda on culture and the creative economy, having the CDCE at its heart. At the national and international levels, they should pursue the SDGs and economic growth through the strengthening of creative industries. To capitalize on their creative assets, the BRICS agenda on culture and the creative economy should notably comprise the following elements:

1. Collaboration to identify weaknesses and strengths in the BRICS countries' creative sectors for appropriate policies to be implemented, allowing the creation of a favorable environment for cultural and creative industries;

2. Innovative partnerships at the local level among the civil society and the public and private sectors as well as the promotion of creative cities;

3. Dialogue on cultural policies and exchange of best practices, the significant differences existing among these countries' creative sectors being an indication that they might learn considerably from each other in varied cultural fields;

4. Based on the 2015 BRICS Agreement on Cooperation in the Field of Culture, collaboration to promote exchanges of cultural goods and

${ }^{44}$ For a discussion on this matter, see RIJDEC, 'Les directives opérationnelles et autres techniques de mise en œuvre de la convention sur la diversité des expressions culturelles dans un contexte numérique' (2015), p. 18, presented at UNESCO in June 2015. 
services among the BRICS countries and to develop their cultural and creative industries;

5. Welding the BRICS around issues regarding global cultural governance, with the aim of leading to ratification of the CDCE by Russia, promoting the CDCE as a framework for cooperation with regard to cultural and creative industries, and building common positions in different international fora; and

6. Cooperation in favor of least-developed countries in terms of cultural and creative industries, the IFCD and the NDB BRICS being possible sources of financial support.

Setting a strategic agenda in the field of culture and the creative economy requires leadership from a national government or an alliance of BRICS governments with the political will to take the initiative and to provide the substantial human and financial resources needed to implement such an agenda. It also requires the building of a strong BRICS partnership and support for a more decisive role for organizations of cultural professionals, both in the BRICS space and worldwide. In fact, strong synergies among civil society organizations in the cultural field in the BRICS countries are a condition for the effective implementation of this agenda and for improving their influence on external cultural affairs.

\section{References}

Accioli, Claudio, Iaquinto, Kalinka, Monteiro, Solange and Thimoteo, Thais, 'Can Brazil become a creative economy?' (2011) The Brazilian Economy 20-28.

BRICS, 'Agreement between the Governments of the BRICS States on Cooperation in the Field of Culture' (Ufa, Russia, 2015); available at www.brics.utoronto .ca/docs/150709-culture-agreement-en.html, [accessed on 5 April 2016].

CISAC, The Creative Industries and the BRICS - A Review of the State of the Creative Economy in Brazil, Russia, India, China and South Africa (CISAC, 2014); available at www.cisac.org/Media/Studies-and-Reports/PublicationsPDF-files/CISAC-BRICS-STUDY-20146 [accessed on 4 April 2016].

European Audiovisual Observatory, Focus: World Film Market Trends (Strasbourg: European Audiovisual Observatory, 2005-2016).

Indian Express, '8th BRICS Summit Goa Declaration', 16 October 2016; available at http://indianexpress.com/article/india/india-news-india/8th-brics-summitgoa-declaration-here-is-the-full-text-adopted-by-the-member-nations/ [accessed on 1 December 2016].

Kauark, Giuliana and Richieri Hanania, Lilian, 'Social and Cultural Development through Cultural Diversity - The Living Culture Programme', in Mapping Cultural Diversity - Good Practices from around the Globe (Asia-Europe 
FOR A BRICS AGENDA ON CULTURE AND THE CREATIVE ECONOMY 349

Foundation, German Commission for UNESCO and U40 Group, 2010), pp. 17-21; available at www.unesco.de/fileadmin/medien/Dokumente/ Kultur/U40/Mapping_Cultural_Diversity_FINAL.pdf [accessed on 4 April 2016].

McClory, Jonathan, 'Creative Russia: Lessons from Berlin', The Guardian, 2013; available at www.theguardian.com/culture-professionals-network/ culture-professionals-blog/2013/sep/25/russia-culture-st-petersburg-berlin [accessed on 8 March 2016].

Neuwirth, Rostam J., 'Global Market Integration and the Creative Economy: The Paradox of Industry Convergence and Regulatory Divergence' (2015) 18(1) Journal of International Economic Law 21-50.

'The UNESCO Convention and Future Technologies: A Journey to the Center of Cultural Law and Policymaking, in Lilian Richieri Hanania and Anne-Thida Norodom (eds.), Diversity of Cultural Expressions in the Digital Era (Buenos Aires: Teseo, 2016); available at www.teseopress.com/ diversityofculturalexpressionsinthedigitalera/ [accessed on 4 April 2016].

Relatório periódico quadrienal sobre as medidas para proteger e promover a diversidade das expressões culturais (2012); available at http://en.unesco .org/creativity/sites/creativity/files/periodic_reports/old/brazil_report_ ownformat_pt_2012.pdf [accessed on 5 April 2016].

Richieri Hanania, Lilian, 'Bringing Cultural Diversity to Discussions on Social and Labor Issues', in Lilian Richieri Hanania (ed.), Cultural Diversity in International Law: The Effectiveness of the UNESCO Convention on the Protection and Promotion of the Diversity of Cultural Expressions (London/New York: Routledge, 2014), pp. 121-135.

(ed.), Cultural Diversity in International Law: The Effectiveness of the UNESCO Convention on the Protection and Promotion of the Diversity of Cultural Expressions (London: Routledge, 2014).

Diversité culturelle et droit international du commerce (Paris: La Documentation française, 2009).

'Le débat commerce-culture à l'ère numérique: quelle application pour la Convention de l'UNESCO sur la diversité des expressions culturelles?' (2015); available at http://papers.ssrn.com/sol3/papers.cfm?abstract_id=2600647 [accessed on 4 April 2016].

'L'extension de l'exception culturelle aux secteurs issus des nouvelles technologies', in RIJDEC - Réseau international des juristes pour la diversité des expressions culturelles, Le renouvellement de l'exception culturelle à l'ère du numérique, 25 October 2015; available at www.coalitionfrancaise.org/wpcontent/uploads/2015/10/RIJDEC-Le-renouvellement-de-lexceptionculturelle-\%C3\%A0-1\%C3\%A8re-du-num\%C3\%A9rique-22-10-15.pdf [accessed on 4 April 2016].

'Protection Mechanisms for Cultural Expressions under Threat' (2014) 2 Transnational Dispute Management - Art and Heritage Disputes 2-6; 
available at www.transnational-dispute-management.com/article.asp?key= 2095 [accessed on 4 April 2016].

'The UNESCO Convention on the Diversity of Cultural Expressions as a Coordination Framework to Promote Regulatory Coherence in the Creative Economy' (2015) International Journal of Cultural Policy 1-20.

RIJDEC, 'Les directives opérationnelles et autres techniques de mise en œuvre de la convention sur la diversité des expressions culturelles dans un contexte numérique' (2015), presented at UNESCO June 2015.

Rossiyskaya, Gazeta, 'Moscow will Host the World Summit for Creative Industries', Russia beyond the Headlines, 20 March 2014; available at http://rbth.com/ business_calendar/2014/03/04/moscow_will_host_the_world_summit_for_ creative_industries_34761.html [accessed on 8 March 2016].

Ruutu, Katja, Panfilo, Aleksander, and Karhunen, Päivi, Cultural Industries in Russia - Northern Dimension Partnership on Culture (2009), pp. 9-10; available at www.northerndimension.info/images/Cultural_Industries_in_Russia.pdf [accessed on 4 April 2016].

UNCTAD, United Nations Conference on Trade and Development, World Creative Economy Report 2010 - Creative Economy: A Feasible Development Option (Geneva: UNCTAD, 2010); available at http://unctad.org/en/Docs/ ditctab20103_en.pdf [accessed on 25 March 2016].

UNESCO, Avant-projet de Convention sur la protection de la diversité des contenus culturels et des expressions artistiques: Partie II: commentaires spécifiques des Etats-membres (Paris, 2004).

Convention on the Protection and Promotion of the Diversity of Cultural Expressions (Paris, 2005); available at http://en.unesco.org/creativity/convention/ about/2005-convention-text [accessed on 25 March 2016].

'The Hangzhou Declaration: Heralding the Next Era of Human Development'; available at www.unesco.org/new/en/culture/themes/dynamic-contentsingle-view/news/the_hangzhou_declaration_heralding_the_next_era_ of_human_development/\#.Vw5mtKSLShc [accessed on 13 April 2016].

'List of Attendees to the Hangzhou Congress'; available at www.unesco.org/new/ fileadmin/MULTIMEDIA/HQ/CLT/pdf/Book15.pdf [accessed on 13 April 2016]

'Periodic Reports - Innovative Examples'; available at http://en.unesco.org/ creativity/monitoring-and-reporting/periodic-reports/innovative-examples [accessed on 13 April 2016].

'Universal Declaration on Cultural Diversity' (Paris, 2001); available at http://unesdoc.unesco.org/images/0012/001271/127162e.pdf [accessed on 22 March 2016].

UNESCO Creative Cities Network, 'Why creativity? Why cities?' 2016; available at http://en.unesco.org/creative-cities/content/why-creativity-why-cities [accessed on 30 March 2016]. 
UNESCO and UNESCO Institute for Statistics (UIS), 'Cultural Trade Flows Infographic' (2016); available at www.uis.unesco.org/culture/Documents/ cult-trade-infographic-final-EN.pdf [accessed on 22 March 2016].

'The Globalisation of Cultural Trade: A Shift in Consumption - International Flows of Cultural Goods and Services 2004-2013' (2016); available at www.uis.unesco.org/culture/Documents/international-flows-culturalgoods-report-en.pdf [accessed on 22 March 2016].

UNESCO-UNDP, Creative Economy Report 2013 Special Edition: Widening Local Development Pathways (Paris: UNESCO-UNDP, 2013).

United Nations, 'Transforming our World: The 2030 Agenda for Sustainable Development', Resolution adopted by the General Assembly on 25 September 2015, Seventieth session, A/RES/70/1, 21 October 2015; available at www.un .org/ga/search/view_doc.asp?symbol=A/RES/70/1\&Lang=E [accessed on 16 March 2016].

Vlassis, Antonios, 'Culture development and technical and financial assistance on the basis of the Convention', in Lilian Richieri Hanania (ed.), Cultural Diversity in International Law: The Effectiveness of the UNESCO Convention on the Protection and Promotion of the Diversity of Cultural Expressions (London: Routledge, 2014), pp. 167-80.

'Culture in the Post-2015 Development Agenda: The Anatomy of an International Mobilization' (2015) 36(9) Third World Quarterly 1649-62.

Gouvernance mondiale et culture: de l'exception à la diversité (Liège: Presses universitaires de Liège, 2015).

'Les puissances émergentes dans la bataille mondiale de l'attraction: Bollywood, vecteur du soft power de l'Inde' (2016) 55 Interventions Économiques 1-21; available at https://interventionseconomiques.revues.org/2867 [accessed on 4 April 2016].

'Soft Power, Global Governance and Rising Powers: The Case of China' (2016) 22(4) International Journal of Cultural Policy 481-96. 